\title{
KARAKTERISTIK PETIR INDONESIA DAN PENGGUNAANNYA DALAM EVALUASI UNJUK KERJA SALURAN UDARA 150 KV SAAT TERJADI SAMBARAN PETIR
}

\author{
Brian Bramantyo S.D.A. Harsono ${ }^{1)}$, Andreas Putro Purnomoadi' ${ }^{2}$, Putu Agus Aditya Pramana ${ }^{3)}$ \\ ${ }^{1,3)}$ PT PLN (Persero) Pusat Penelitian dan Pengembangan Ketenagalistrikan \\ ${ }^{2)}$ Satuan Pusat Keunggulan PT PLN (Persero) Kantor Pusat \\ Email: brian.adiputro@pln.co.id ${ }^{1)}$ \\ Asal Negara: Indonesia
}

\begin{abstract}
ABSTRAK
Berdasarkan data historis, gangguan saluran transmisi udara di Indonesia mayoritas disebabkan oleh sambaran petir; hal tersebut mendorong PT PLN (Persero) sebagai perusahaan listrik milik negara untuk mengevaluasi unjuk kerja saluran udara terhadap sambaran petir. Pada makalah ini disajikan evaluasi karakterisasi petir menggunakan rekam data sistem deteksi petir/LDS (studi kasus untuk Jawa Barat) meliputi: jumlah sambaran, persentase polaritas, nilai modus arus puncak, persentase kejadian kumulatif, serta peta kerapatan petir. Evaluasi unjuk kerja saluran dilakukan melalui: 1) simulasi tegangan lebih menggunakan perangkat lunak transient pada pemodelan saluran $150 \mathrm{kV}$ untuk mengetahui korelasi arus puncak petir terhadap kenaikan tegangan pada insulator saat terjadi sambaran petir, dan 2) evaluasi sudut lindung menggunakan Electro Geo-metric Model (EGM). Berdasarkan pengolahan data tahun 2018-2020, terdapat fluktuasi total kejadian petir per tahun dimana $84,63 \%(\sigma=1,71)$ dari kejadian merupakan petir polaritas negatif. Modus nilai arus puncak petir adalah 12,33 kA $(\sigma=1,52)$, sementara persentase kejadian kumulatif memiliki knee point pada nilai $40 \mathrm{kA}$. Pola kerapatan petir tertinggi tidak mengalami perbedaan signifikan selama periode pengamatan dan bulan ke-7 merupakan periode dengan kejadian petir terendah. Hasil simulasi sambaran petir $40 \mathrm{kA}$ pada kawat pembumian menunjukkan bahwa insulator mengalami kenaikan tegangan hingga $1083 \mathrm{kV}$; hal tersebut mendekati nilai Basic Impulse Insulation Level (BIL) dari insulator. Desain sudut lindung mampu mencegah shielding failure untuk arus petir $\geq 11 \mathrm{kA}$; meskipun demikian, perlu dicatat bahwa shielding failure akibat petir $10 \mathrm{kA}$ menyebabkan kenaikan tegangan insulator melebihi nilai BIL. Peningkatan unjuk kerja saluran transmisi $150 \mathrm{kV}$ tersebut dapat dilakukan dengan didasari oleh pertimbangan risk, cost dan benefit yang komprehensif.
\end{abstract}

Kata kunci: Karakterisasi petir, kerapatan petir, saluran udara, pemodelan, BIL

\section{ABSTRACT}

According to historical data, most of the overhead transmission line fault in Indonesia was caused by a lightning strike; therefore, PT PLN (Persero), as a state-owned electricity company, evaluated the performance of overhead line's performance against lightning strikes. This paper presents an evaluation of lightning characteristics based on lightning detection system/LDS recorded data (West Java region used as a case study) which include: total lightning per year, polarity percentage, most frequent lightning peak current, cumulative event percentage, and ground flash density. Overhead transmission line evaluation is performed by using: 1) overvoltage simulation at a $150 \mathrm{kV}$ overhead line model using transient software to obtain the correlation between lightning peak current and overvoltage across insulator string during lightning strike event, and 2) shielding angle evaluation using Electro Geometric Model (EGM). According to the data recorded within 2018-2020, there is a fluctuation of total lightning events per year with $84,63 \%(\sigma=1,71)$ of the entire event is negative lightning. Modus of the lightning peak current per year is 12,33 kA $(\sigma=1,52)$, while the cumulative event's knee point is 40 $k A$. The lightning density pattern is relatively similar during three years observation and the period with the lowest lightning activity is in July. Simulation result for $40 \mathrm{kA}$ lightning strike toward ground wire showed that the overvoltage across the insulator string could reach $1083 \mathrm{kV}$, which is very close to the Basic Impulse Insulation Level (BIL) of the insulator string itself. Shielding angle design is capable to protect the overhead line from shielding failure caused by a lightning strike with $\geq 11 \mathrm{kA}$ peak current; however, shielding failure due to 10 $k A$ lightning creates overvoltage across the insulator string above its BIL value. It is possible to improve the performance of $150 \mathrm{kV}$ overhead transmission line toward a lightning strike as long it is supported with comprehensive risk, cost, and benefits evaluation.

Keywords: lightning characteristic, lightning density, overhead transmission line, model, BIL

1. PENDAHULUAN
Fenomena tegangan lebih dapat dibagi menjadi 4 jenis, yaitu: 1) Temporary sustained 
overvoltage yang merupakan fenomena tegangan lebih frekuensi daya akibat load rejection, proses pemberian tegangan, dan resonansi; 2) Slow front overvoltage yang merupakan fenomena tegangan lebih akibat pensaklaran pada gardu induk; 3) Fast front overvoltage yang merupakan fenomena tegangan lebih akibat sambaran petir; dan 4) Veryfast front overvoltage yang merupakan fenomena tegangan lebih proses pensaklaran pada peralatan gardu induk dengan insulasi gas.

Indonesia merupakan salah satu negara dengan kerapatan petir yang tinggi seperti yang ditunjukkan pada Gambar 1 (Holle and Brooks, 2019); hal tersebut dapat berpengaruh pada paparan sambaran petir pada saluran transmisi yang ada. Berdasarkan evaluasi yanag dilakukan unit pengelola transmisi PT PLN (Persero) terhadap data gangguan pada tahun 2015-2019, dapat diketahui bahwa petir merupakan salah satu penyebab utama gangguan saluran transmisi udara yang dimiliki PLN.

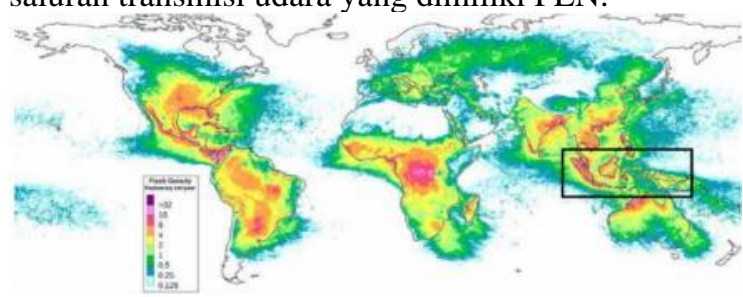

Gambar 1. Peta kerapatan petir dunia untuk periode 2014-2018 (Holle and Brooks, 2019)

Sejak tahun 2017, PLN telah membangun sistem deteksi petir untuk memonitor aktivitas petir yang ada di sebagian wilayah kerjanya. Sistem ini menggunakan 22 sensor deteksi gelombang elektromagnetik frekuensi rendah (LF) yang terintegrasi dengan pusat pengolah data yang ada di PLN Puslitbang. Data yang dihasilkan dari sistem deteksi petir tersebut meliputi: perkiraan lokasi dan waktu sambaran, perkiraan nilai arus puncak, jenis sambaran, serta polaritas. Terkait dengan penentuan lokasi sambaran, sistem deteksi petir yang digunakan PLN menggunakan gabungan dua metode, yaitu magnetic direction finder (MDF) dan metode time of arrival (ToA). Metode MDF memerlukan 2 antena cross-loop (Betz et al., 2009; Lu et al., 2020) pada satu titik pembacaan sehingga dapat diketahui simpangan sudut antara utara absolut dengan titik terjadinya sambaran; minimal 2 titik pembacaan dibutuhkan untuk mengetahui lokasi terjadinya sambaran. Metode ToA menggabungkan data waktu tiba gelombang elektromagnetik dari minimal 3 titik pembacaan untuk dapat mengetahui perkiraan lokasi sambaran (Wang et al., 2020). Dengan menggunakan gabungan dari kedua metode tersebut, sistem deteksi petir PLN mampu merekam kejadian sambaran petir secara realtime serta mampu menyimpan rekam kejadian sambaran petir sejak tahun 2017 untuk keperluan analisis historis. Meskipun demikian, penggunaan data dari sistem deteksi petir PLN mayoritas digunakan untuk evaluasi ada tidaknya pengaruh petir pada satu kejadian gangguan penghantar.

Berdasarkan gap analysis yang dilakukan terhadap literatur terkait, dapat diketahui bahwa pada umumnya penelitian terkait rekam data petir digunakan untuk mendapatkan total kejadian, perbandingan polaritas, serta modus dari nilai arus puncak sambaran petir (Chi et al., 2014; Kai, 2011; Rufus et al., 2019; Wang et al., 2019) sementara untuk sistem ketanagalistrikan, rekam data petir dapat diolah untuk mendapatkan peta kerapatan petir atau ground flash density (GFD) (Kai, 2011; Wang et al., 2019) untuk keperluan desain saluran baru maupun peningkatan unjuk kerja dari saluran transmisi eksisting. Belum terdapat literatur terkait review karakterisasi petir di Indonesia untuk periode lebih dari 1 tahun observasi serta pemanfaatannya dalam evaluasi saluran transmisi udara. Mempertimbangkan hasil gap analysis serta melihat ketersediaan rekam data petir yang dimiliki PLN untuk periode waktu 2018-2020, maka pada makalah ini akan dilakukan: 1) karakterisasi petir dengan studi kasus provinsi Jawa Barat; dan 2) evaluasi unjuk kerja saluran transmisi udara eksisting melalui simulasi tegangan lebih untuk mengetahui korelasi nilai arus puncak (berdasarkan data petir yang didapatkan) terhadap kenaikan tegangan saat sambaran pada kawat pembumian maupun pada kawat fasa. Kedua hal tersebut dapat digunakan sebagai masukan dalam evaluasi unjuk kerja saluran transmisi yang ada terhadap sambaran petir.

\section{METODE}

Metode yang digunakan untuk memenuhi tujuan dari penelitian ini dapat dinyatakan dalam beberapa tahap. Tahap pertama adalah pengumpulan data petir dari sistem deteksi petir PLN untuk periode 2018 - 2020. Data petir yang digunakan adalah data sambaran petir ke bumi/cloud-to-ground khususnya return stroke yang pertama (satu kejadian sambaran petir bisa terdiri atas lebih dari 1 return stroke). Tahap kedua adalah pengolahan rekam data petir untuk mendapatkan pola karakterisasi tahunan sebagai berikut: jumlah total sambaran, rasio polaritas sambaran, modus nilai arus puncak yang terekam, serta persentasi kejadian kumulatif. Selain itu, rekam data yang diperoleh dinyatakan secara spasial pada wilayah provinsi Jawa Barat untuk mendapatkan GFD. Tahap ketiga adalah pengumpulan data geometris tower dan saluran untuk pemodelan tegangan tinggi yang disebabkan akibat sambaran petir. Pemodelan dilakukan dengan bantuan perangkat lunak transien. Untuk makalah ini, digunakan saluran $150 \mathrm{kV}$; sehingga pemodelan yang digunakan adalah menggunakan distributed line (Adi Kusuma et al., 2018) seperti yang dinyatakan pada Gambar 2. Pendekatan nilai impedansi surja dari metode distributed line dapat dihitung menggunakan persamaan (1) dan persamaan (2). 


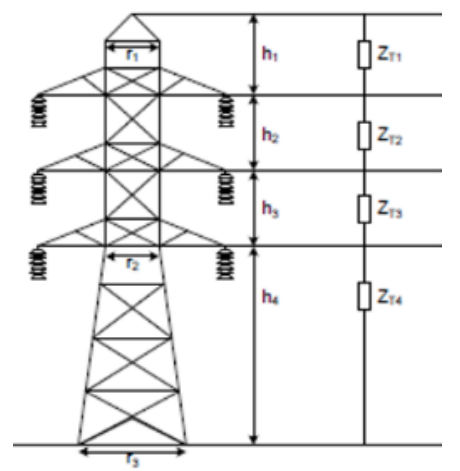

Gambar 2. Representasi tower $150 \mathrm{kV}$ menggunakan metode distributed line

$$
\begin{aligned}
& Z_{T i}=60\left\{\ln \left(\frac{H}{R}\right)-1\right\} \\
& R=\frac{\left(r_{1} l_{2}+r_{2} H+r_{3} l_{1}\right)}{2 H}
\end{aligned}
$$

Dimana $\mathrm{Z}_{\mathrm{Ti}}$ : nilai impedansi surja untuk tiap segmen tower $(\Omega), \mathrm{H}$ : tinggi tower $(\mathrm{m}), \mathrm{R}$ : radius ekivalen dari tower $(\mathrm{m}), \mathrm{r}_{1}$ : radius bentuk kerucut untuk bagian puncak tower $(\mathrm{m}), \mathrm{r}_{2}$ : radius bentuk kerucut untuk bagian tengah tower $(\mathrm{m}), \mathrm{r}_{3}$ : radius bentuk kerucut untuk bagian dasar tower $(\mathrm{m}), \mathrm{l}_{1}$ : tinggi dari dasar tower hingga tengah tower $(\mathrm{m})$, dan $\mathrm{l}_{2}$ : tinggi dari dasar tengah tower hingga puncak tower (m). Tahap keempat adalah evaluasi unjuk kerja saluran transmisi melalui: 1) simulasi sambaran petir pada kawat fasa maupun kawat pembumian menggunakan perangkat lunak transien berdasarkan nilai arus puncak yang diperoleh untuk mengetahui besarnya kenaikan tegangan yang dialami oleh insulator; dan 2) Evaluasi menggunakan metode Electro-Geometric Model (EGM) dilakukan untuk mengetahui pada arus puncak berapa terjadi shielding failure pada saluran transmisi. Pendekatan menggunakan EGM dilakukan untuk mengetahui pada arus puncak berapa terjadi shielding failure (Distribution Committee, 1997). Perumusan radius sambar petir menurut IEEE dapat menggunakan persamaan (3) (Distribution Committee, 1997).

$$
r=A I^{b}
$$

Dimana $r$ : radius sambar $(\mathrm{m}), \mathrm{A}=10, \mathrm{~b}=0,65$, dan $\mathrm{I}$ : arus puncak (kA).

\section{HASIL DAN PEMBAHASAN}

\subsection{Karakterisasi Petir}

Berdasarkan data yang diperoleh untuk rentang waktu 2018-2019, maka karakterisasi petir di wilayah Jawa Barat dapat diperoleh sejumlah temuan sebagai berikut: 1) pada tahun 2018, terdapat total 295.774 kejadian petir dengan $85,95 \%$ data berupa petir dengan polaritas negatif dengan modus nilai arus puncak petir berada pada angka 14 kA (10.771 kejadian); 2) pada tahun 2019, terdapat total 374.624 kejadian petir dengan $85,26 \%$ data berupa petir dengan polaritas negatif dengan modus nilai arus puncak petir berada pada angka $12 \mathrm{kA}$ (12.610 kejadian); dan 3) pada tahun 2020, terdapat total 289.172 kejadian petir dengan $82,70 \%$ data berupa petir dengan polaritas negatif. Modus nilai arus puncak petir berada pada angka 11 kA (9.553 kejadian). Terdapat fluktuasi total sambaran petir yang terjadi, dimana terjadi kenaikan pada tahun 2019 kemudian mengalami penurunan pada tahun 2020; hal tersebut sangat berkaitan dengan dinamika cuaca yang terjadi selama periode observasi. Selain itu, sekitar $84,63 \% \quad(\sigma=1,71) \quad$ kejadian petir merupakan petir polaritas negatif, dengan modus nilai arus puncak $12,33 \mathrm{kA}(\sigma=1,52)$. Persentase kumulatif kejadian petir dapat dilihat pada Gambar 3, dimana jumlah kejadian yang tertinggi (memiliki gradien lebih curam) berada di daerah dibawah 40 $\mathrm{kA}$. Knee point $40 \mathrm{kA}$ berada pada persentase kejadian kumulatif $\geq 85 \%$.

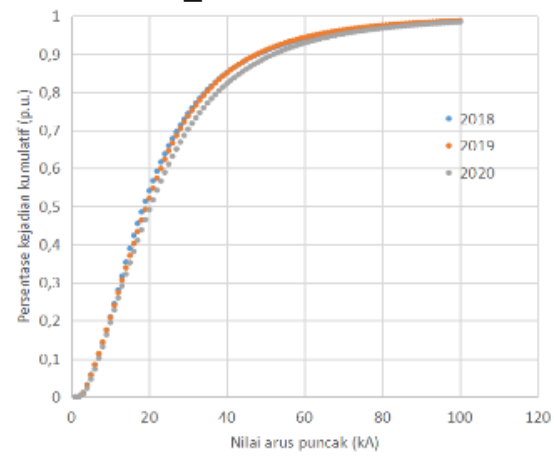

Gambar 3. Presentase kumulatif kejadian petir

Berdasarkan hasil evaluasi nilai modus, dapat diketahui bahwa nilai arus puncak petir di Jawa Barat berkisar antara 11-14 kA dengan median (50\% dari nilai presentasi kejadian kumulatif) $20 \mathrm{kA}$; hal tersebut menyerupai dengan median kejadian petir di negara lain, contohnya adalah Australia yang berkisar 21 kA (Nampak et al., 2021) atau di Amerika yang berkisar 23,1 kA Cummins et al., 2019). Apabila dilihat bahwa besarnya nilai modus dari kejadian petir di Jawa Barat berada di bawah nilai mediannya (Gambar 3), maka potensi terjadinya kegagalan shielding failure pada saluran transmisi menjadi lebih besar oleh karena mayoritas kejadian petir memiliki radius sambar yang kecil. Hal tersebut dapat dievauasi lebih lanjut pada bagian 3.2 menggunakan pendekatan EGM. Adanya $15 \%$ kejadian petir di atas knee point $40 \mathrm{kA}$ berpotensi menyebabkan sambaran pada kawat pembumian atau struktur dari tower (radius sambar yang dimiliki besar; hal ini dapat diverifikasi menggunakan pendekatan EGM). Besarnya nilai tegangan lebih yang terjadi pada insulator akibat sambaran petir $11 \mathrm{kA}$ pada kawat fasa serta sambaran petir $40 \mathrm{kA}$ pada kawat pembumian akan dievaluasi lebih lanjut pada bagian 3.2 .

Variasi bulanan dari rekam kejadian petir dapat dilihat pada Gambar 4, dimana nilai kejadian petir 
terendah terjadi pada bulan Juli. Pola tersebut berkebalikan dengan belahan bumi selatan (Australia) yang memiliki kejadian petir paling sedikit saat musim dingin (Nampak et al., 2021) maupun pada belahan bumi utara (Eropa) yang memiliki kejadian petir paling rendah di triwulan pertama (Avotniece et al., 2017). Hal tersebut menunjukkan karakteristik daerah tropis yang hanya memiliki dua musim; pertengahan tahun pada periode 2018-2020 merupakan musim kemarau dengan intensitas kejadian petir yang rendah. Temuan ini dapat dipergunakan sebagai masukan dalam penjadwalan pemeliharaan saluran udara, dimana mayoritas pemeliharaan dapat dilakukan pada bulan Juli.

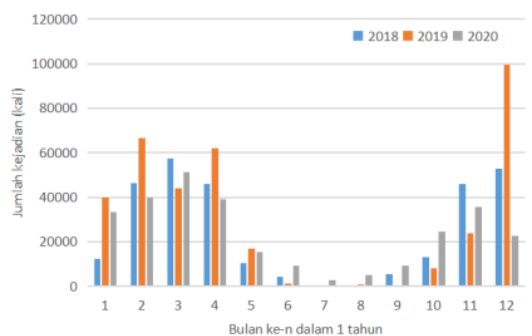

Gambar 4. Sebaran kejadian petir per bulan
Pemetaan rekam data petir pada wilayah Jawa Barat dengan grid $5 \mathrm{~km}$ x $5 \mathrm{~km}$ menghasilkan peta kerapatan/GFD seperti yang dinyatakan pada Gambar 4 - Gambar 6. Kerapatan petir untuk Jawa Barat bagian tengah secara konsisten lebih tinggi dibandingkan bagian yang lain dari tahun 2018 hingga 2020, sementara daerah dengan kerapatan petir tertinggi adalah Bogor (GFD tertinggi mencpai 45,42 sambaran/km2/tahun pada tahun 2019). Nilai kerapatan petir tersebut lebih tinggi dibandingkan kerapatan petir di daerah Eropa yang berkisar 0,1-4 sambaran/km2/tahun maupun di Amerika yang berkisar 14 sambaran/km2/tahun (Holle and Cummins, 2010; Javor et al., 2018). Kerapatan petir yang tinggi menunjukkan tingginya kerawanan peralatan terhadap sambaran petir, Khususnya pada saluran transmisi udara yang memiliki ketinggian tower di atas 30-40 meter (lebih tinggi daripada objek yang ada di sekitar), perencanaan sudut lindung, pembumian, maupun koordinasi insulasi harus dilakukan dengan cermat untuk mendapatkan unjuk kerja salura terhadap sambaran petir yang lebih baik. Apabila dipadukan dengan sebaran kejadian petir per nilai arus puncak pada Gambar 3, maka perlu dipertimbangkan penggunaan sudut lindung 0 derajat atau minus untuk memberikan ketahanan yang lebih baik terhadap shielding failure (Distribution Committee, 1997).

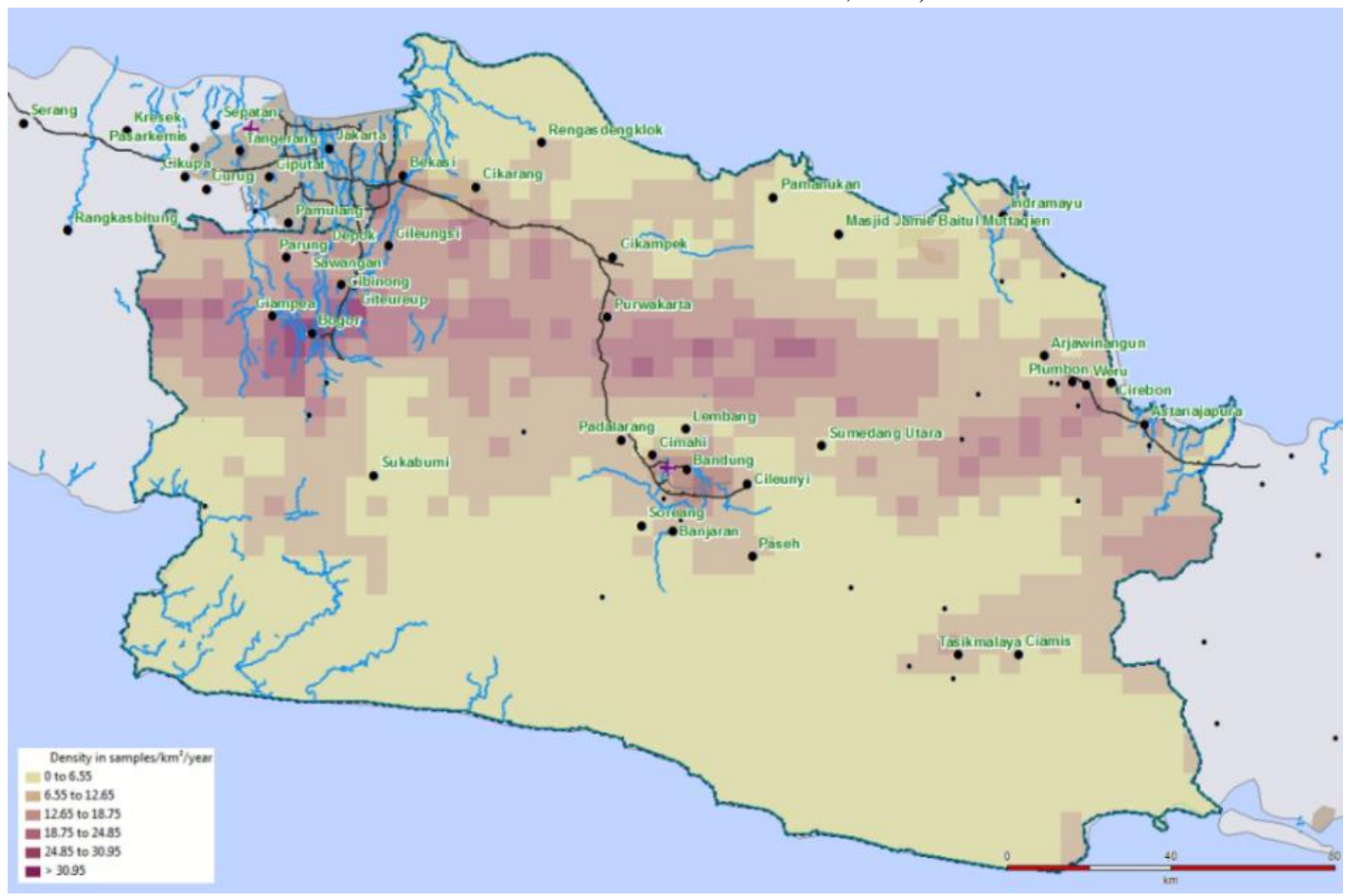

Gambar 5. Peta kerapatan petir Jawa Barat tahun 2018 (ukuran grid $5 \mathrm{~km}$ x $5 \mathrm{~km}$ ) 


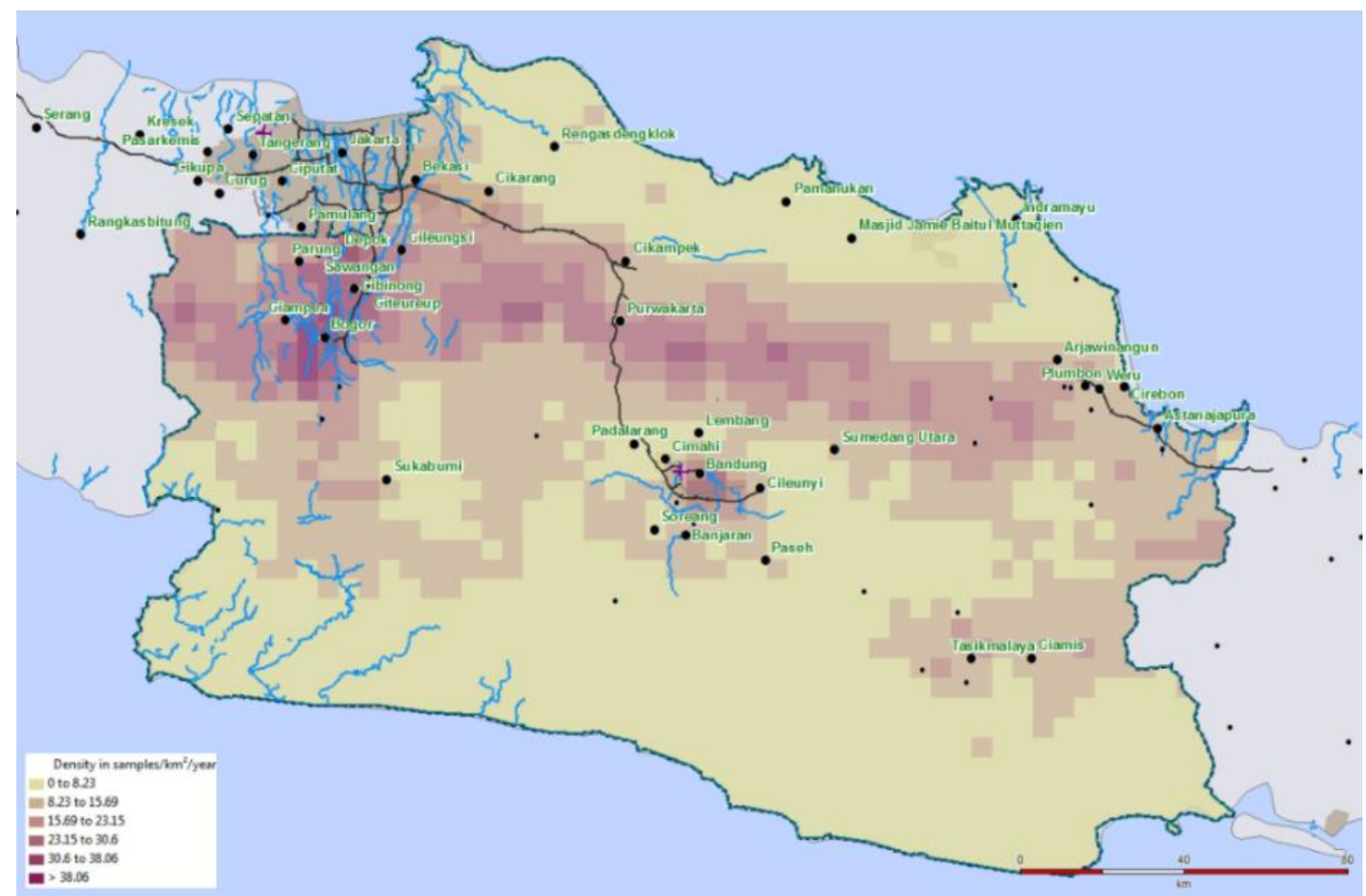

Gambar 6. Peta kerapatan petir Jawa Barat tahun 2019 (ukuran grid $5 \mathrm{~km}$ x 5 km)

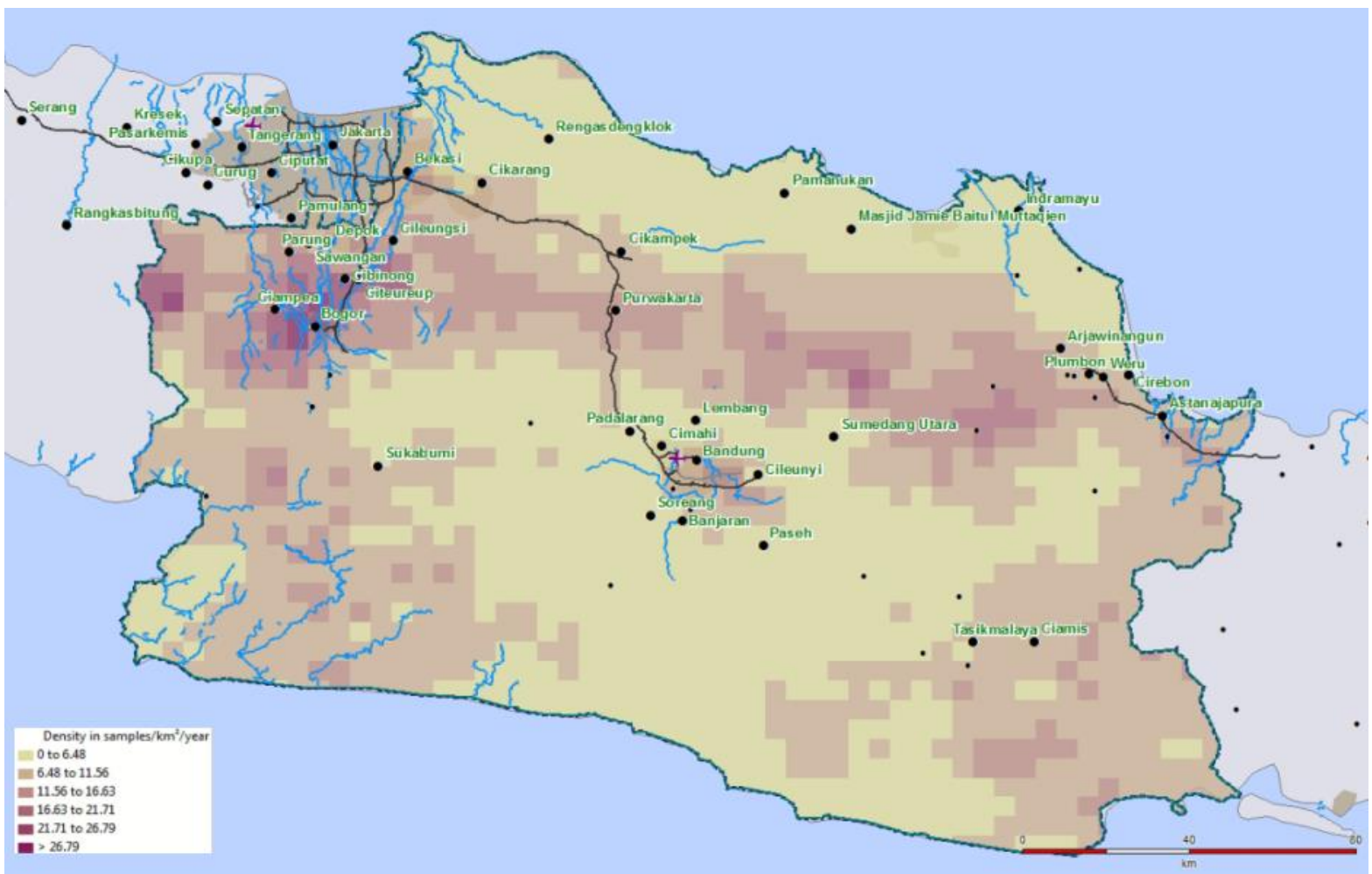

Gambar 7. Peta kerapatan petir Jawa Barat tahun 2020 (ukuran grid $5 \mathrm{~km}$ x $5 \mathrm{~km}$ )

\subsection{Simulasi Fenomena Tegangan Lebih akibat Sambaran Petir}

Parameter tower dan saluran eksisting yang digunakan dalam simulasi ini dapat dinyatakan pada 
Tabel I dan Tabel II; parameter tersebut digunakan dalam persamaan (1) dan (2) sehingga diperoleh pemodelan yang digunakan untuk simulasi tegangan lebih akibat sambaran petir dapat dilihat pada Gambar 8.

Tabel 1

Parameter tower eksisting

\begin{tabular}{ccc}
\hline Parameter & Nilai & Satuan \\
\hline $\mathrm{H}$ & 38,2 & $\mathrm{~m}$ \\
$\mathrm{r}_{1}$ & 2,06 & $\mathrm{~m}$ \\
$\mathrm{r}_{2}$ & 2,06 & $\mathrm{~m}$ \\
$\mathrm{r}_{3}$ & 5,5 & $\mathrm{~m}$ \\
$\mathrm{l}_{1}$ & 24,75 & $\mathrm{~m}$ \\
$\mathrm{l}_{2}$ & 13,45 & $\mathrm{~m}$ \\
\hline
\end{tabular}

Tabel 2

Parameter konduktor dan kawat pembumian eksisting

\begin{tabular}{|c|c|c|}
\hline \multicolumn{3}{|c|}{ Konduktor: ACSR 240/40 mm2 } \\
\hline Parameter & Nilai & Satuan \\
\hline Outer radius & 9,481 & $\mathrm{~mm}$ \\
\hline Inner radius & 3,545 & $\mathrm{~mm}$ \\
\hline DC resistance $(300 C)$ & 0,1247 & $\Omega$ \\
\hline \multicolumn{3}{|c|}{ Kawat pembumian:GSW 55 mm2 } \\
\hline Parameter & Nilai & Satuan \\
\hline Outer radius & 4,183 & $\mathrm{~mm}$ \\
\hline Inner radius & 0 & $\mathrm{~mm}$ \\
\hline DC resistance $(300 C)$ & 1,35 & $\Omega$ \\
\hline
\end{tabular}

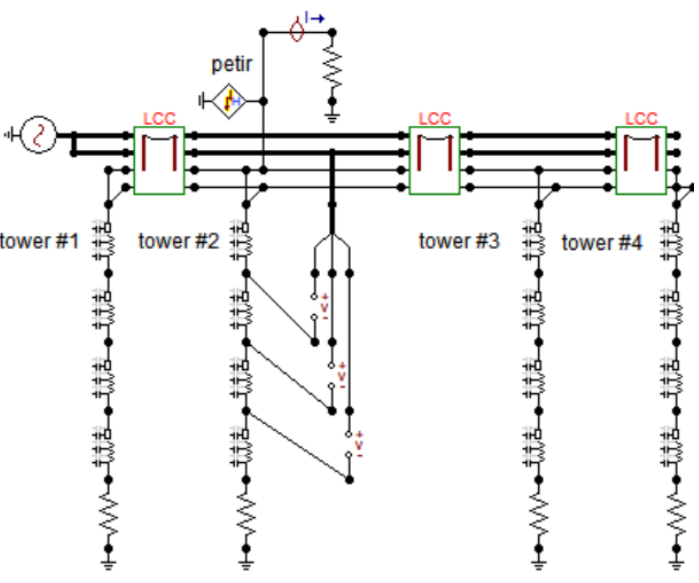

Gambar 8. Pemodelan untuk simulasi tegangan lebih

Berdasarkan karakteristiknya, sambaran petir dapat mengenai kawat pembumian/struktur tower sehingga menyebabkan back flash over (BFO) maupun dapat mengenai kawat fasa jika terjadi kegagalan perlindungan (shielding failure). Untuk simulasi yang pertama, dilakukan pengkondisian di mana petir menyambar pada kawat pembumian. Apabila digunakan modus nilai arus puncak petir yang terjadi pada tahun 2018 - 2019, maka besarnya kenaikan tegangan tertinggi dapat ditunjukkan pada Tabel III. Nilai kenaikan tegangan yang terjadi masih berada dibawah nilai Basic Impule Insulation Level (BIL) dari 11-12 keping insulator, yaitu sekitar $1080 \mathrm{kV}$; dengan demikian, sambaran petir dengan nilai 11-14 kA tidak akan menyebabkan flashover pada insulator. Apabila menggunakan data kejadian kumulatif pada knee point, yaitu $40 \mathrm{kA}$ (Gambar 3), maka besarnya kenaikan tegangan yang muncul mencapai $1083 \mathrm{kVp}$ line to ground (Gambar 9); hal tersebut berpotensi menyebabkan flashover.

Tabel 3. Kenaikan tegangan pada insulator string saat terjadi sambaran pada kawat pembumian

\begin{tabular}{cc}
\hline $\begin{array}{c}\text { Arus puncak } \\
(\mathbf{k A})\end{array}$ & Kenaikan tegangan tertinggi \\
\hline 11 & $363 \mathrm{kVp}$ line to ground \\
12 & $388 \mathrm{kVp}$ line to ground \\
14 & $438 \mathrm{kVp}$ line to ground \\
\hline
\end{tabular}

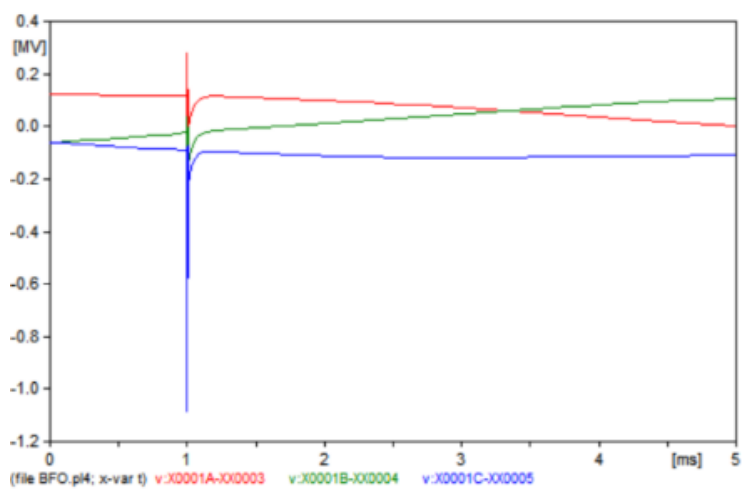

Gambar 9. Kenaikan tegangan saluran pada saat sambaran petir dengan nilai arus puncak $40 \mathrm{kA}$ di kawat pembumian

Pada kondisi sambaran langsung ke kawat fasa paling atas dengan menggunakan nilai modus arus puncak (11 kA), terjadi kenaikan tegangan hingga $1268 \mathrm{kVp}$ line to ground yang melewati nilai BIL dari insulator yang digunakan (Gambar 10).

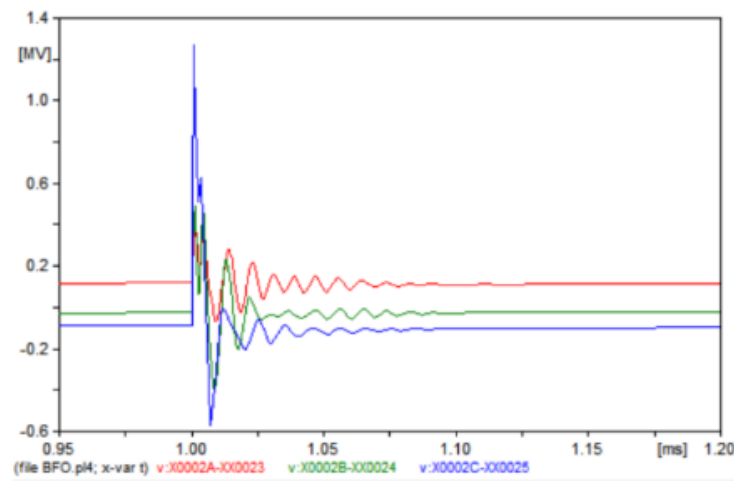

Gambar 10. Kenaikan tegangan saluran pada saat sambaran petir dengan nilai arus puncak $11 \mathrm{kA}$ di kawat fasa

Berdasarkan analisis EGM, dapat dilihat bahwa petir dengan nilai puncak $\geq 11 \mathrm{kA}$ memiliki kecenderungan untuk menyambar kawat pembumian (Gambar 11). Meskipun demikian, perlu dipertimbangkan bahwa petir dengan nilai arus puncak $10 \mathrm{kA}$ memiliki potensi menyebabkan 
kegagalan sudut lindung serta dapat menyebabkan kenaikan tegangan hingga $1144 \mathrm{kVp}$ line to ground.

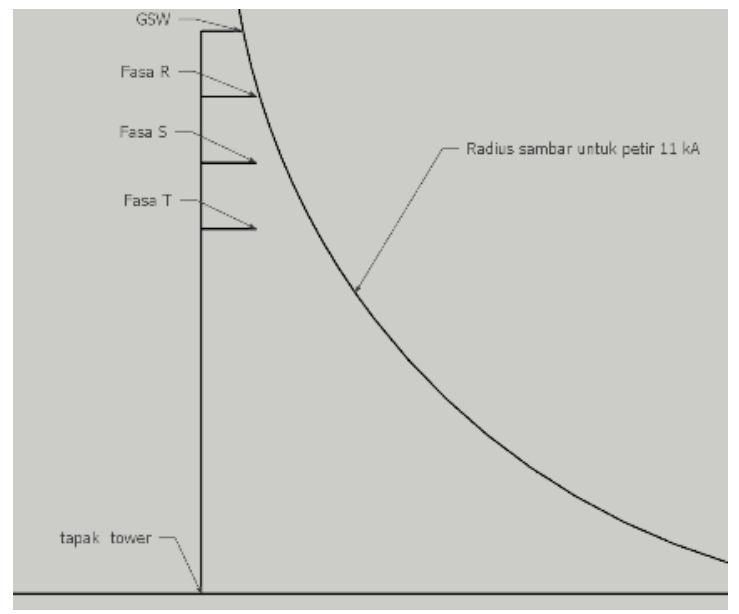

Gambar 11. Evaluasi EGM pada geometri tower yang digunakan

Tegangan lebih akibat sambaran petir yang dialami oleh saluran sangat berkaitan dengan nilai ketahanan insulasi impuls/BIL yang digunakan. Pada umumnya, saluran insulator menggunakan renteng insulator yang terdiri dari 11-12 keping dengan nilai BIL berkisar 1040 - 1080 kV. Apabila dibandingkan dengan kenaikan nilai tegangan yang ditunjukkan pada Gambar 9, maka dapat diketahui bahwa sambaran petir $40 \mathrm{kA}$ pada saluran transmisi $150 \mathrm{kV}$ (untuk desain/geometri yang dinyatakan pada Tabel 1) dapat menyebabkan terjadinya gangguan satu fasa tanah karena BFO. Mengacu pada persentase kejadian kumulatif yang dinyatakan pada Gambar 3, desain saluran mampu menahan $85 \%$ dari persentase kejadian kumulatif petir yang telah terjadi sebelumnya. Meskipun demikian, mitigasi dari $15 \%$ dari kejadian petir (diatas $40 \mathrm{kA}$ ) yang dapat menyebabkan gangguan harus dievaluasi dari sisi risk, cost dan benefit; contohnya: apabila diinginkan perlindungan terhadap $15 \%$ kejadian tersebut, maka perlu dilakukan perhitungan ulang dari koordinasi insulasi saluran (penggunaan BIL yang lebih tinggi) hingga penambahan transmission line arrester (TLA) untuk pemotongan tegangan lebih yang memerlukan biaya investasi dan O\&M lebih besar.

Sambaran pada kawat fasa menyebabkan kenaikan tegangan yang lebih tinggi dibandingkan sambaran pada kawat pembumian (Gambar 10). Hasil evaluasi menggunakan metode EGM menunjukkan bahwa saluran dengan desain yang dinyatakan pada Tabel I berpotensi mengalami kegagalan sudut lindung pada petir dengan nilai arus puncak $10 \mathrm{kA}$. Tegangan lebih yang disebabkan dari sambaran petir $10 \mathrm{kA}$ pada kawat pembumian melebihi nilai BIL dari 11-12 keping insulator sehingga besarnya nilai sudut lindung eksisting perlu dievaluasi kembali. Sama seperti mitigasi untuk 15\% kejadian petir di atas $40 \mathrm{kA}$ yang dapat menyebabkan potensi $\mathrm{BFO}$, peningkatan kehandalan terhadap shielding failure melalui pengurangan besar nilai sudut lindung (hingga 0 atau bahkan minus) perlu dievaluasi lebih lanjut dengan mempertimbangkan sisi risk, cost dan benefit.

\section{KESIMPULAN DAN SARAN}

Berdasarkan evaluasi dan analisis data yang telah dilakukan, untuk wilayah observasi Jawa Barat pada periode tahun 2018-2020 dapat diketahui bahwa terdapat fluktuasi total kejadian petir dalam 1 tahun di Jawa Barat dimana 84,63\% $(\sigma=1,71)$ dari kejadian merupakan petir polaritas negatif dan modus nilai arus puncak petir adalah $12,33 \mathrm{kA}(\sigma=1,52)$. Pola persentase kumulatif kejadian petir memiliki pola yang sama, yaitu terdapat knee poin pada nilai $40 \mathrm{kA}$. Variasi pola bulanan menunjukkan bahwa petir terendah terjadi pada bulan Juli. Pola kerapatan petir pada wilayah Jawa Barat relatif konstan untuk bagian tengah, dengan nilai tertinggi pada daerah Bogor (45,42 sambaran/km2/tahun pada tahun 2019). Evaluasi unjuk kerja saluran udara $150 \mathrm{kV}$ telah dilakukan melalui simulasi tegangan lebih pada pemodelan saluran udara $150 \mathrm{kV}$ untuk kondisi sambaran pada kawat pembumian maupun kawat fasa dengan nilai puncak berdasarkan karakterisasi petir yang telah dilakukan serta melalui metode pendekatan EGM. Desain saluran udara $150 \mathrm{kV}$ memiliki potensi mengalami gangguan akibat BFO pada sambaran petir $>40 \mathrm{kA}$ pada kawat pembumian oleh karena kenaikan tegangan yang dialami oleh insulator telah melewati nilai Basic Impulse Insulation Level (BIL). Desain sudut lindung yang digunakan pada saluran udara $150 \mathrm{kV}$ mampu mencegah shielding failure untuk arus petir $\geq 11 \mathrm{kA}$; meskipun demikian, perlu dicatat bahwa shielding failure akibat petir $10 \mathrm{kA}$ menyebabkan kenaikan tegangan insulator melebihi nilai BIL. Peningkatan unjuk kerja saluran transmisi $150 \mathrm{kV}$ tersebut dapat dilakukan, namun perlu dipertimbangkan dari sisi risk, cost dan benefit yang diperoleh.

\section{DAFTAR PUSTAKA}

Adi Kusuma, Aristo, Putu Agus Aditya Pramana, Brian Bramantyo S. D. A. Harsono, and Buyung Sofiarto Munir. 2018. "Effect of Indirect Lightning Strike to $66 \mathrm{kV}$ Transmission Line in Java-Bali System." MATEC Web of Conferences 197:1-7. doi: 10.1051/matecconf/201819711001.

Avotniece, Zanita, Agrita Briede, Maris Klavins, and Svetlana Aniskevich. 2017. "Remote Sensing Observations of Thunderstorm Features in Latvia." Environmental and Climate Technologies 21(1):28-46. doi: 10.1515/rtuect-2017-0014.

Betz, Hans Dieter, Ulrich Schumann, and Pierre Laroche. 2009. "Lightning: Principles, Instruments and Applications: Review of Modern Lightning Research." Lightning: Principles, Instruments and Applications: 
Review of Modern Lightning Research 1-641. doi: 10.1007/978-1-4020-9079-0.

Chi, Gongbo, Yang Zhang, Dong Zheng, Weitao Lu, and Yijun Zhang. 2014. "Characteristics of Lightning Activities in Potala Palace Region of Tibet." 2014 International Conference on Lightning Protection, ICLP 2014 (41205002):1992-94. doi: 10.1109/ICLP.2014.6973455.

Distribution Committee. 1997. IEEE Guide for Improving the Lightning Performance of Transmission Lines.

Cummins, Kenneth L., Jennifer G. Wilson, and Amy S. Eichenbaum. 2019. "The Impact of CloudTo-Ground Lightning Type on the Differences in Return Stroke Peak Current over Land and Ocean." IEEE Access 7:174774-81. doi: 10.1109/ACCESS.2019.2956685.

Holle, Ronald, and William Brooks. 2019. "Vaisala 2018 Annual Lightning Report.” 14.

Holle, Ronald L., and Kenneth L. Cummins. 2010. "Monthly Distributions of U.S. Nldn Cloud-toGround Lightning." 21st International Lightning Detection Conference/21st International Lightning Meteorology Conference 13.

Javor, Vesna, Leonid Stoimenov, Nikola Džaković, Nikola Dinkić, Dario Javor, and Hans Dieter Betz. 2018. "LINETGIS Analysis of Lightning Flash Density in Serbia Based on Ten Years Data." Serbian Journal of Electrical Engineering 15(2):201-11. doi: 10.2298/SJEE1802201J.

Kai, X. U. 2011. "Cloud-to-Ground Lightning Characteristics in Yunnan Province from 2006 to 2010 (IMPACT Methodkriging Method with Gaussian Smoothing.” (2009):2009-12.

Lu, Zhigang, Shi Qiu, Ruichao Wang, Lihua Shi, and Peng Zhang. 2020. "Orientation of Initial Breakdown Pulses and Leader Discharges by Magnetic Direction Finder." Journal of Geophysical Research: Atmospheres 125(6):113. doi: 10.1029/2019JD031407.

Nampak, Haleh, Peter Love, Paul Fox-Hughes, Christopher Watson, Jagannath Aryal, and Rebecca M. B. Harris. 2021. "Characterizing Spatial and Temporal Variability of Lightning Activity Associated with Wildfire over Tasmania, Australia." Fire 4(1):1-22. doi: 10.3390/fire4010010.

Rufus, Shirley Anak, N. A. Ahmad, Z. Abdul-Malek, and Noradlina Abdullah. 2019. "Characteristics of Lightning Trends in Peninsular Malaysia from 2011 to 2016." ICECOS 2019 - 3rd International Conference on Electrical Engineering and Computer Science, Proceeding 15-18. doi: 10.1109/ICECOS47637.2019.8984514.

Wang, Jiaquan, Qiming Ma, Xiao Zhou, Fang Xiao, Shangbo Yuan, Sheng Chang, Jin He, Hao
Wang, and Qijun Huang. 2020. “Asia-Pacific Lightning Location Network (APLLN) and Preliminary Performance Assessment." Remote Sensing 12(10):1-21. doi: 10.3390/rs12101537.

Wang, Yu, Hantao Tao, Shanqiang Gu, Yang Chen, Wanxing Feng, and Yuangen Xu. 2019. "Cloud-to-Ground Lightning Activity in Guangdong Province, South China during the Period 2004-2017." 2019 11th Asia-Pacific International Conference on Lightning, APL 2019 1-5. doi: 10.1109/APL.2019.8816012. 